\title{
Targeted Molecular Therapy: From its Evolution to Current Scenario in Oral Squamous Cell Carcinoma
}

\author{
Dr. Kavita Gupta*, Dr. Leeky Mohanty, Dr. Chaitanya N. Babu
}

The Oxford Dental College, Bangalore, India

DOI: $10.36347 /$ sjds.2020.v07i12.001

| Received: 18.11 .2020 | Accepted: 01.12.2020 | Published: 05.12.2020

*Corresponding author: Dr. Kavita Gupta

\section{Abstract}

Original Research Article

Oral squamous cell carcinoma of head and neck is associated with high morbidity and mortality in both western and Asian countries. The development of oral squamous cell carcinoma is a multistep process, which requires the accumulation of multiple genetic alternations and is influenced by a patient's genetic predisposition as well as by environmental factors such as tobacco, alcohol, chronic inflammation and viral infection. Targeted therapies are specific method which interferes with some aspects of cellular life without harming healthy cells and hence they will work by interfering with specific molecules involved in carcinogenesis and tumour growth. Thus by altering molecular and cellular changes that are specific to cancer, molecular targeted therapies may be more effective than conventional therapies i.e. radiation, surgery and chemotherapy. The use of molecular targeted therapies is relatively new and new discoveries are emerging at a rapid pace. This paper will discuss the history of molecular targeted therapy and its present scenario in oral squamous cell carcinoma.

Keywords: Targeted molecular therapy, oral squamous cell carcinoma.

Copyright $($ C) 2020 The Author(s): This is an open-access article distributed under the terms of the Creative Commons Attribution 4.0 International License (CC BY-NC 4.0) which permits unrestricted use, distribution, and reproduction in any medium for non-commercial use provided the original author and source are credited.

\section{INTRODUCTION}

Oral squamous cell carcinoma (OSCC) is one of the most common malignancy seen throughout the world. The morbidity and mortality due to OSCC is not even reduced after the introduction of traditional treatments like surgery, radiotherapy and chemotherapy. Hence new treatment modalities are required to improve the overall survival rate. The desire to targeted therapy is not new, although the use of word has taken on greater prominence in recent years, in this they specifically interact with diseased cells while leaving other cells of the host unaffected. The transition to rationally designed, molecularly targeted drugs occurred in the period from 1990 to the present, following a dramatic expansion of knowledge of the molecular drivers of cell transformation and there identification for specific signalling pathways that control the proliferation to cell death, angiogenesis and metabolism. In this Imagine was the first rationally designed, low molecular weight inhibitor to achieve clinical success. Identification of this oncogenic driver provided the molecular basis for the stratification of patients with non-small-cell lung cancer (NSCLC) with sensitizing epithelial growth factor receptor (EGFR) mutations. At the same time, trastuzumab (1992), a monoclonal antibody against the human epidermal growth factor receptor 2 (HER2), which is amplified in $25 \%$ of breast cancers, dramatically enhanced the efficacy of taxanes and other chemotherapy processes [1]. Other antibodies, including rituximab (1998), which targets CD20 also found to be effective in the treatment of non-Hodgkin's lymphoma [2]. Bevacizumab (2004) a monoclonal antibody that binds the vascular endothelial growth factor (VEGF) and blocks tumour angiogenesis showed similar enhancement in chemotherapy [3]. Following these fundamental discoveries, a series of more than 30 new drugs, all targeted to specific receptors or enzymes has been found useful application in specific subsets of human cancers. The only significant new cytotoxics in the past decade are bendamustine (2008), a unique alkylating agent which is highly active in lymphoid malignancies and available in Europe since the 1980s [4]. Cetuximab to date is the only targeted therapy known to demonstrate an OS benefit in HNSCC, both in locally advance setting i.e. combination with radiotherapy [6] and in the first-line recurrent and/or metastatic (R/M) setting in combination with chemotherapy [5]. It is a monoclonal antibody which targets the epidermal growth factor receptor (EGFR). Eribulin, a marine natural product is found to be active in breast cancer (Scarpace, 2012); and trabectedin (2015) which is also a marine natural product found to 
be useful in second-line treatment of sarcomas. The epidermal growth factor receptor (EGFR) inhibitors such as gefitinib and erlotinib were also used with variable success in a small number of patients before the identification of sensitizing EGFR mutations.

\section{MATERIALS AND METHOD}

Comprehensive reviews of the available previous literature relevant to molecular targeted therapy in oral squamous cell carcinoma were undertaken. References for this review were identified through searches of PubMed with the search terms Molecular targeted therapy and oral squamous cell carcinoma up to September 2020. Only full length articles in English language were selected. Final references list was generated on the basis of originality and relevance while writing this review article.

\section{DISCUSSION}

As we have seen how the development takes place in the field of targeted therapies, more studies have come out in the field of OSCC. NSAIDS Sulindac (2002) effectiveness on growth cell cycle and apoptosis in human OSCC cell lines were examined, supporting the significant time and dose dependent cell growth inhibitory effect of NSAIDS and its anticancer effect. In this both the mechanisms are involved i.e. COX dependent mechanism activation and induction of PPAR- $\gamma$ expression [7]. Sonoporation (2009) with antiepidermal growth factor receptor (EGFR) was used for developing a specific drug delivery system for OSCC. Administration of low dose of bleomycin produces marked growth inhibition of Ca $9-22$ cells in vitro and decreases the apoptopic cell indicating that sonoporation with $\mathrm{Fab}$ fragment makes drug administration for OSCC more efficient and specific. With EGFR over expression implicating a poor prognosis, it was one of the first biomarkers targeted as a potential therapy for HNSCC [8]. In this study (2011) GL12, one of the main transcriptional activators of HH/GL1 signalling, only 44\% patients expresses GL12 after surgery as compared to $77 \%$ of tumours who lack GL12 expression. Thus both cyclopamine and GAN+61 effectively inhibit GL1 expression. Slowed cellular growth, promoted G1 arrest, increased appoptosis and migration of OSCC cells, suggest that the expression of GL12 is strongly associated with the poor outcome of OSCC patients. This data suggest a subset of OSCC patients benefitting for anti-HH/GL1 therapies [9]. FOXO3a (2011) is a transcriptional regulator which regulates a wide range of biological processes. FOXO3 activity modulation and anti-tumour effects of OSCC cells were studied revealing that Rapamycin / cisplantin combination therapy will boost the synergistic anti tumour effect through reactivation of FOXO3 thus can be used as a potent molecular targeted strategy for OSCC [10]. In this study (2011) they apply 'antikinome' and 'anti- phosphatome' lentiviral shRNA subset to high throughput screen and identified the potential biomarkers of OSCC cells. These markers along with their pathways can be used for early diagnosis and for developing specific medicines for OSCC [11]. Interferon $-\gamma($ IFN $-\gamma)$ a cytokine which is produced and secreted by inflammatory cells in the tumour microenvironment are the main stimulator of PDL-1 expression in tumour cell but a significant decrease is seen after PKD2 knock down with shRNA/siRNA interference. Results show that PKD2 activation not only inhibits PD-4 expression but also promotes anti-tumour effect and decreases the drug resistance [12]. Microarray analysis (2013) was done to determine the gene expression in nine human OSCC and non -neoplastic keratinocyte cell line. Expression level of Aurokinase A (AURKA) mRNA and protein were examined. Result shows over expression of AURKA in tissues. Small interfering RNAs (siAURKA) suppresses the expression of AURKA protein (31-89\%) and reduction of MLN8237 (38 $74 \%$ ) shows critical role of AURKA in growth of human OSCC cells. Suggesting that targeting AURKA can be used as a therapeutic strategy for OSCC [13]. Activation of TLR-9 dose and time dependent migration and invasion of HB cells signalling (2014) could promote human oral cancer $\mathrm{HB}$ cells. Invasion with induction of MMP-2 by increasing the AP-1 binding activity suggest novel anti-metastatic application for TLR-9 targeted therapy [14]. Livin is the most important member of Inhibitor protein (IAP) family and in this they have investigated expression of livin protein in OSCC tissues using western blot analysis and IHC. Results shows increased expression of Livin in human OSCC tissues as compared to normal adjacent mucosa [15]. Buparlisib which targets PI3K shows an OS benefit in combination with paclitaxel as compared with paclitaxel alone, independent of $\mathrm{PI} 3 \mathrm{~K} / \mathrm{AKT} / \mathrm{mTORpathway}$ alterations $[16,17]$. In the latter study patients with HPV-negative tumors, TP53 alterations, and low mutational load derive a better benefit from the addition of buparlisib to paclitaxel [17]. A phase III clinical trial has been launched. Cetuximab has been the most successful targeted therapy applied in OSCC to date, it is a monoclonal antibody which is directed against the extracellular receptor domain of EGFR, blocks ligand binding and subsequent downstream signalling, in addition to its role in the long-term down regulation of the receptor expression. In a phase III clinical trial by Bonner et al., cetuximab in combination with radiotherapy provided an overall survival benefit of an additional 20 months compared to radiation alone [18]. There have also been several clinical trials comparing chemotherapy alone or in combination with cetuximab. In the phase III trial, Erbitux in first-line treatment of recurrent or metastatic head and neck cancer (EXTREME), 442 patients with recurrent or metastatic HNSCC were randomized to receive either platinum/5-FU alone or cetuximab plus platinum/5-FU. Results showed an increase in response rate from $20 \%$ in the chemotherapy group to $36 \%$ in the chemotherapy plus cetuximab group, with an overall survival increase from 7.4 months in the chemotherapy 
group to 10.1 months in the chemotherapy and in the cetuximab group [19]. Another phase III clinical trial from the Radiation Therapy Oncology Group (RTOG) comparing concurrent chemo radiation and Cisplatin versus concurrent chemo radiation with Cisplatin and cetuximab in patients with stage III and IV HNSCC is pending [20]. In addition to monoclonal antibodies targeting EGFR, small molecule tyrosine kinase inhibitors (TKIs) are also capable of inhibiting EGFR function. Phase I and II clinical trials in patients with recurrent or metastatic HNSCC have been conducted on the TKIs erlotinib and gefitinib. With erlotinib, these trials show an overall survival range of six to eight months and a response rate from $4 \%$ to $21 \%$. With gefitinib, phase I and II clinical trials have demonstrated an overall survival ranging from six to eight months, with a response rate of $1 \%$ to $15 \%$ [2125]. While studies of erlotinib and gefitinib have demonstrated some response in HNSCC, results of phase III clinical trials on TKIs are still pending [20]. Angiogenesis play an very important and significant role in tumor growth and progression [22-29]. VEGF has been shown to be overexpressed in tumour cells compared to normal cells; this over expression is associated with a 1.88-fold increased risk of death and is found to be associated with lymph node metastasis [24]. There are several antiangiogenic targets currently undergoing clinical trial. Tyrosine kinase inhibitors of the VEGF receptors halt their intracellular signalling. Several of these small molecule tyrosine kinase inhibitors, sunitinib, sorafenib, vandetanib, semaxanib, and foretinib, are undergoing phase II clinical trials [20]. But they have many adverse effects. Another receptor tyrosine kinase of potential interest in OSCC is the Eph receptor family and its ligands, the Ephrins. This group of proteins has an important role in many physiologic processes including cell aggregation and migration, angiogenesis, and vascular network development [25]. Anticancer agents commonly used in combination with radiotherapy, including cisplatin, carboplatin, 5-fluorouracil (5FU), and cetuximab, have demonstrated single-agent efficacy in HNSCC patients. Some molecular targeted therapies have been studied in combination with radiotherapy despite lacking singleagent activity, such as bortezomib (proteasome inhibitor) or lapatinib (dual EGFR/HER2 inhibitor) [30, 31]. These trials are key to identify the biomarkers of efficacy and accuracy for molecular targeted therapies in OSCC. They seem to be safe and provide clinical benefits in some patients, but they are not easy to conduct and their use in regular treatment armentarium is still a future endeavour.

\section{CONCLUSION}

New molecular targeted therapies are inducing several consistent and major improvements in oral squamous cell carcinoma management. Most of the clinical development of targeted therapy in HNSCC has actually been performed in the R/M setting. The two main strategies in this setting are a chemo-additive strategy and development as a single agent. In the first case, the objective is to increase the usefulness of standard-of-care chemotherapy by overcoming primary and/or secondary resistance to treatment by adding a molecular targeted therapy, whereas in the latter case the objective is to get a new drug in the treatment. As a class, they have good bioavailability, a slow rate of metabolism, and favourable distribution, and all the other properties that can be put into the clinical candidate in the preclinical phase of development. However, unfavourable effects in humans are difficult to predict at various preclinical and clinical stages. Offtarget toxicities and drug interactions emerge during clinical testing and can present serious hurdles to further clinical development. Hence Understanding and dealing with these pharmacological properties is a very critical step in successful drug development and then its further use in OSCC treatment protocol.

\section{REFERENCS}

1. Hudis CA. Trastuzumab-mechanism of action and use in clinical practice. New England Journal of Medicine. 2007 Jul 5;357(1):39-51.

2. The American Society of Health-System Pharmacists.

3. Shih T, Lindley C. Bevacizumab: an angiogenesis inhibitor for the treatment of solid malignancies. Clinical therapeutics. 2006 Nov 1;28(11):1779802.

4. Weide R, Hess G, Köppler H, Heymanns J, Thomalla J, Aldaoud A, Losem C, Schmitz S, Haak U, Huber C, Unterhalt M. High antilymphoma activity of bendamustine / mitoxantrone / rituximab in rituximab pretreated relapsed or refractory indolent lymphomas and mantle cell lymphomas. A multicenter phase II study of the German Low Grade Lymphoma Study Group (GLSG). Leukemia \& lymphoma. 2007 Jan 1;48(7):1299-306.

5. Vermorken JB, Mesia R, Rivera F, Remenar E, Kawecki A, Rottey S, Erfan J, Zabolotnyy D, Kienzer HR, Cupissol D, Peyrade F. Platinumbased chemotherapy plus cetuximab in head and neck cancer. New England Journal of Medicine. 2008 Sep 11;359(11):1116-27.

6. Bonner JA, Harari PM, Giralt J, Azarnia N, Shin DM, Cohen RB, Jones CU, Sur R, Raben D, Jassem J, Ove R. Radiotherapy plus cetuximab for squamous-cell carcinoma of the head and neck. New England Journal of Medicine. 2006 Feb 9;354(6):567-78.

7. Nikitakis NG, Hebert C, Lopes MA, Reynolds MA, Sauk JJ. PPAR $\gamma$ mediated antineoplastic effect of NSAID sulindac on human oral squamous carcinoma cells. International journal of cancer. 2002 Apr 20;98(6):817-23.

8. Maeda H, Tominaga K, Iwanaga K, Nagao F, Habu M, Tsujisawa T, Seta Y, Toyoshima K, Fukuda JI, Nishihara T. Targeted drug delivery system for oral cancer therapy using sonoporation. 
Journal of oral pathology \& medicine. 2009 Aug;38(7):572-9.

9. Yan M, Wang L, Zuo H, Zhang Z, Chen W, Mao L, Zhang P. HH/GLI signalling as a new therapeutic target for patients with oral squamous cell carcinoma. J Oral pathol Med. 2011 sep;45(6)432-9.

10. Fang L, Wang $\mathrm{H}$, Zhou L, Yu D. FOXO3a reactivation mediates the synergistic cytotoxic effects of rapamycin and cisplatin in oral squamous cell carcinoma cells. Toxicology and applied pharmacology. 2011 Feb 15;251(1):8-15.

11. Yeh MH, Tsai TC, Kuo HP, Chang NW, Lee MR, Chung JG, Tsai MH, Liu JY, Kao MC. Lentiviral short hairpin RNA screen of human kinases and phosphatases to identify potential biomarkers in oral squamous cancer cells. Int J Oncol. 2011 Nov; 39(5):1221-31.

12. Chen J, Feng Y, Lu L, Wang H, Dai L, Li Y, Zhang P. Interferon- $\gamma$-induced PD-L1 surface expression on human oral squamous carcinoma via PKD2 signal pathway. Immunobiology. 2012 Apr 1;217(4):385-93.

13. Tanaka H, Nakashiro K, Iwamoto K, Tokuzen N, Fujita Y, Shirakawa R, Oka R, Goda H, Hamakawa H. Targeting Aurora kinase A suppresses the growth of human oral squamous cell carcinoma cells in vitro and in vivo. Oral Oncol. 2013 Jun; 49(6):551-9.

14. Ruan M, Zhang Z, Li S, Yan M, Liu S, Yang W, Wang L, Zhang C. Activation of Toll-like receptor-9 promotes cellular migration via upregulating MMP-2 expression in oral squamous cell carcinoma. PloS one. 2014 Mar 21;9(3):e92748.

15. Lee DH, Yoon TM, Kim S, Park YL, Lee KH, Lim SC, Lee JK, Joo YE. Relationship between expression of Livin and the biological behavior of human oral squamous cell carcinoma. Oncology reports. 2014 Dec 1;32(6):2453-60.

16. Soulières D, Faivre S, Mesía R, Remenár É, Li SH, Karpenko A, Dechaphunkul A, Ochsenreither S, Kiss LA, Lin JC, Nagarkar R. Buparlisib and paclitaxel in patients with platinum-pretreated recurrent or metastatic squamous cell carcinoma of the head and neck (BERIL-1): a randomised, double-blind, placebo-controlled phase 2 trial. The Lancet Oncology. 2017 Mar 1;18(3):323-35.

17. Soulières D, Licitra L, Mesía R, Remenár É, Li SH, Karpenko A, Chol M, Wang YA, Solovieff N, Bourdeau L, Sellami D. Molecular alterations and buparlisib efficacy in patients with squamous cell carcinoma of the head and neck: biomarker analysis from BERIL-1. Clinical cancer research. 2018 Jun 1;24(11):2505-16.

18. Vermorken JB, Mesia R, Rivera F, Remenar E, Kawecki A, Rottey S, Erfan J, Zabolotnyy D, Kienzer HR, Cupissol D, Peyrade F. Platinumbased chemotherapy plus cetuximab in head and neck cancer. New England Journal of Medicine. 2008 Sep 11;359(11):1116-27.

19. Bonner JA, Harari PM, Giralt J, Azarnia N, Shin DM, Cohen RB, Jones CU, Sur R, Raben D, Jassem J, Ove R. Radiotherapy plus cetuximab for squamous-cell carcinoma of the head and neck. New England Journal of Medicine. 2006 Feb 9;354(6):567-78.

20. Cancer Genome Atlas Network. Comprehensive genomic characterization of head and neck squamous cell carcinomas. Nature. 2015 Jan;517(7536):576-82.

21. Seiwert TY, Zuo Z, Keck MK, Khattri A, Pedamallu CS, Stricker T, Brown C, Pugh TJ, Stojanov P, Cho J, Lawrence MS. Integrative and comparative genomic analysis of HPV-positive and HPV-negative head and neck squamous cell carcinomas. Clinical cancer research. 2015 Feb 1;21(3):632-41.

22. O'Sullivan B, Huang SH, Siu LL, Waldron J, Zhao H, Perez-Ordonez B, Weinreb I, Kim J, Ringash J, Bayley A, Dawson LA. Deintensification candidate subgroups in human papillomavirusrelated oropharyngeal cancer according to minimal risk of distant metastasis. Journal of clinical oncology. 2013 Feb 10;31(5):543-50.

23. Weinstein IB, Joe A. Oncogene addiction. Cancer Res. 2008; 68(9):3077-3080.

24. McLornan DP, List A, Mufti GJ. Applying synthetic lethality for the selective targeting of cancer. N Engl J Med. 2014; 371(18):1725-1735.

25. Muller FL, Colla S, Aquilanti E, Manzo VE, Genovese G, Lee J, Eisenson D, Narurkar R, Deng P, Nezi L, Lee MA. Passenger deletions generate therapeutic vulnerabilities in cancer. Nature. 2012 Aug;488(7411):337-42.

26. Ferris RL, Blumenschein Jr G, Fayette J, Guigay J, Colevas AD, Licitra L, Harrington K, Kasper S, Vokes EE, Even C, Worden F. Nivolumab for recurrent squamous-cell carcinoma of the head and neck. N Engl J Med. 2016 Nov 10;375:185667.

27. Cohen EE, Soulières D, Le Tourneau C, Dinis J, Licitra L, Ahn MJ, Soria A, Machiels JP, Mach N, Mehra R, Burtness B. Pembrolizumab versus methotrexate, docetaxel, or cetuximab for recurrent or metastatic head-and-neck squamous cell carcinoma (KEYNOTE-040): a randomised, open-label, phase 3 study. The Lancet. 2019 Jan 12;393(10167):156-67.

28. Ferris RL, Blumenschein Jr G, Fayette J, Guigay J, Colevas AD, Licitra L, Harrington KJ, Kasper S, Vokes EE, Even C, Worden F. Nivolumab vs investigator's choice in recurrent or metastatic squamous cell carcinoma of the head and neck: 2 year long-term survival update of CheckMate 141 with analyses by tumor PD-L1 expression. Oral oncology. 2018 Jun 1;81:45-51.

29. Burtness B, Harrington KJ, Greil R, Soulières D, Tahara M, De Castro Jr G, Psyrri A, Baste Rotllan 
Kavita Gupta et al., Sch J Dent Sci, Dec, 2020; 7(12): 196-200

N, Neupane PC, Bratland A, Fuereder T. LBA8_PR KEYNOTE-048: phase III study of first-line pembrolizumab (P) for recurrent/metastatic head and neck squamous cell carcinoma (R/M HNSCC). Annals of Oncology. 2018 Oct 1;29(suppl_8):mdy424-045.

30. Kubicek GJ, Axelrod RS, Machtay M, Ahn PH, Anne PR, Fogh S, Cognetti D, Myers TJ, Curran Jr WJ, Dicker AP. Phase I trial using the proteasome inhibitor bortezomib and concurrent chemoradiotherapy for head-and-neck malignancies. International Journal of Radiation Oncology* Biology* Physics. 2012 Jul 15;83(4):1192-7.

31. Colevas AD, Brown JM, Hahn S, Mitchell J, Camphausen K, Coleman CN. Development of investigational radiation modifiers. Journal of the National Cancer Institute. 2003 May 7;95(9):64651. 